\title{
Bench-to-bedside review: Platelets and active immune functions - new clues for immunopathology?
}

\author{
Olivier Garraud 1,2, , Hind Hamzeh-Cognasse' , Bruno Pozzetto', Jean-Marc Cavaillon³ and Fabrice Cognasse1,2
}

\begin{abstract}
Platelets display a number of properties besides the crucial function of repairing damaged vascular endothelium and stopping bleeding; these are exploited to benefit patients receiving platelet component transfusions, which might categorize them as innate immune cells. For example, platelets specialize in pro-inflammatory activities, and can secrete a large number of molecules, many of which display biological response modifier functions. Platelets also express receptors for non-self-infectious and possibly non-infectious danger signals, and can engage infectious pathogens by mechanisms barely explained beyond observation. This relationship with infectious pathogens may involve other innate immune cells, especially neutrophils. The sophisticated interplay of platelets with bacteria may culminate in sepsis, a severe pathology characterized by significant reductions in platelet count and platelet dysfunction. How this occurs is still not fully understood. Recent findings from in-depth platelet signaling studies reveal the complexity of platelets and some of the ways they evolve along the immune continuum, from beneficial functions exemplified in endothelium repair to deleterious immunopathology as in systemic inflammatory response syndrome and acute vascular diseases. This review discusses the extended role of platelets as immune cells to emphasize their interactions with infectious pathogens sensed as potentially dangerous.
\end{abstract}

\section{Introduction}

Besides being essential to hemostasis, blood platelets have been recently shown to be able to bind infectious agents or engulf them. Clinical observations suggest that thrombocytopenia usually worsens during infection, implying both central and peripheral causes. Platelets constitutively express molecules that are classically acknowledged to function in primary hemostasis. Platelet-associated molecules comprise more than 1,000 proteins: 69 are membrane proteins [1]. Platelets are highly active in shedding their surface molecules [1]. Besides their seminal role in hemostasis, and because they display molecules otherwise known to intervene in immune responses, platelets have been recently shown to actively - and not only passively - participate in immunity.

The immune system is classically viewed as a duality of innate and adaptive immunity, and despite their unique functions they share common intricate properties. The definition of what is unique in innate immunity is imprecise, and may be approached by opposition to what is unique to adaptive immunity. Generally, innate immune cells express invariant receptors, as opposed to adaptive immune cells, which express rearranged receptors [2]. Myeloid originating cells - a family to which megakaryocytes belong - express several receptor families with various functions and platelets have inherited many properties of their ancestry regarding expression of such receptors. Indeed, they can: i) express non-mutated ligands that bind pathogens or pathogenderived structures; ii) express invariant receptors that ease the ingestion of a variety of pathogens by different mechanisms to destroy them or inhibit pathogenicity; iii) secrete a wide array of molecules to communicate with other cells in the microenvironment or at distance to mediate local actions such as inflammation; iv) respond to signaling molecules to activate machinery \footnotetext{
in a polarized manner, either locally or at a distance to fight danger or to repair tissue damage. Expression of all four properties characterizes so-called innate immune cells from non-immune cells, such as endothelial and epithelial cells, that can exert partial immune responses.

2EFS Auvergne-Loire and GIMAP-EA 3064, Université de Saint-Etienne, Faculté de Médecine, 15 rue Ambroise Paré, 42023 Saint-Etienne cedex 2, France Full list of author information is available at the end of the article 
Until recently, platelets would have been considered as non-immune cells with some immune functions.

\section{Platelets express non-mutated receptors that bind pathogens and pathogen-derived structures, which in turn activate them}

Pathogen sensors and ligands on and in platelets

In the mid-1970s, it was shown that platelets could bind lipopolysaccharides (LPSs) using a lipid A moiety [3,4]. Further, pathogen recognition receptors (PRRs) other than classical receptors (CRs and FcRs) were discovered intracellularly and on the surface of human and mouse platelets in 2004/2005. Significantly, most Toll-like receptor (TLR) family members are expressed on and/or in platelets [5-8]. Thus, it is likely that other PRR protein families will also be identified.

Functional PRRs (CRs, FcRs for Igs, TLRs and possibly other receptors) [6] allow platelets to bind foreign microbial invaders and products derived from microbes. This allows platelets to participate in danger sensing, which is typical of innate cells. LPSs from Gram-negative bacteria that bind cell surface MD2/TLR4 complexes and bacterial lipopeptides (or synthetic tri- or diacylpeptides, Pam3CSK4 and Pam2CSK4), which are classical ligands for TLR2 in dimeric association with TLR1 or TLR6, are widely used to investigate physio-pathological interactions of pathogen-associated molecular patterns (PAMPs; infectious danger signatures).

\section{The ligation of pathogen-derived moieties to platelet sensors leads to platelet activation}

LPS-TLR4/MD2 binding is not passive because it is accompanied by rearrangement of other platelet surface molecules, or their membrane expression from the cytosol, such as CD40-ligand (CD40L), a prominent platelet molecule secreted in large quantities upon appropriate stimulation [9]. Whether LPS directly induces platelet activation is still controversial. However, ligation of LPS to human platelet-expressed TLR4 might activate platelets and mobilize other membrane and cytoplasmic molecules. Previously, we demonstrated that LPS from various strains of Gram-negative bacteria could bind TLR4 on human platelets and elicit soluble CD40L secretion dose-dependently, suggesting an adaptive function of platelets within the environment [9]. The consistent failure of several leading groups in the platelet biology field to find evidence of direct and substantial platelet activation after LPS-TLR4/MD2 binding, in particular when testing mouse cells [6], implies that intermediate steps are required. Such intermediate steps for human platelets may include the need for absorption, from plasma, of soluble CD14 on the platelet surface, which is essential in human systems [9]. Studies on direct contacts between platelets and Gram-negative bacteria that display LPS $[6,10,11]$ indicate that platelets can be activated differentially depending on the precise stimulus applied, and that platelets - following their activation secrete elective cytokine profiles [12]; despite the fact that this evidence is experimental, and may barely be extrapolated to real life conditions, it seems rather strong [13].

Further elucidation of these processes is required to make firm conclusions regarding this controversial issue, and consistent proof of this assumption may be extremely relevant in clinics because of the disputed role of platelets in sepsis and questions regarding therapeutic intervention in life-threatening sepsis patients.

\section{Platelet sensors of infectious moieties and thrombosis}

TLR2 is a functional receptor in platelets, as revealed by experimental ligation of the synthetic ligand Pam3CSK4. Subsequent stimulation of TLR2 by Pam3CSK4 and protease-activated receptor 1 (PAR1), an inducer of platelet secretion and aggregation, induced NF- $\mathrm{KB}$ phosphorylation within the platelet inflammasome and differential platelet cytokine and serotonin release [14] (Damien P, Cognasse F, Payrastre B, Spinelli S, Blumberg N, Phipps R, McNichol A, Pozzettto B, Garraud O, Hamzeh-Cognasse $\mathrm{H}$, submitted). Recently, Risitano and colleagues [15] demonstrated in vitro and in vivo in a murine model the visual and functional transfer of RNA associated with platelet-like particles from wild-type to TLR2-deficient mice. However, laboratory findings obtained from ex vivo experiments or in vivo mouse models must be extrapolated to human pathophysiological situations.

In addition to TLR4 and TLR2, TLR9, an intracellular pathogen sensor, is consistently described in association with mouse and human platelets. Panigrahi and colleagues [16] recently demonstrated that platelet TLR9 was functional and linked oxidative stress, innate immunity, and thrombosis. Simultaneously, Thon and colleagues [17] demonstrated TLR9 was stored in a newly defined intracellular compartment in platelets, remarkably extending the basic knowledge of platelet physiology, and helping define a novel mechanism of platelet TLR9 organization and signaling.

\section{How do platelets fight danger? The microbicidal potency of platelets}

Platelets activate cellular machinery to sense and fight danger by using sensors in the form of TLRs, among other PRRs (Table 1). Further, platelets have differential functional programs depending on the bacterial and viral danger they face and can adapt their response to the nature and extent of the stress/danger by favoring specific cytokine secretion [18]. This can be considered characteristic of innate immune cells $[6,19,20]$. 
Table 1. Proposed exogenous and endogenous ligands for principal Toll-like receptors

\begin{tabular}{|c|c|c|c|}
\hline Receptor & Synthetic ligands & Natural ligands & Ligand origin \\
\hline TLR1-2 & Pam3CSK4 & Triacyl lipopeptides & Bacteria and mycobacteria \\
\hline TLR2 & & $\begin{array}{l}\text { Lipoprotein/lipopeptide } \\
\text { Peptidoglycan } \\
\text { Lipoteichoic acid } \\
\text { Lipoarabinomannan } \\
\text { Phenol-soluble modulin } \\
\text { Glycoinositol phospholipids } \\
\text { Glycolipids } \\
\text { Porins } \\
\text { Atypical lipopolysaccharide } \\
\text { Atypical lipopolysaccharide } \\
\text { Zymosan } \\
\text { HSP } 70 \\
\text { Necrotic or dying cells } \\
\text { Versican } \\
\text { Antiphospholipid antibodies } \\
\text { Amyloids }\end{array}$ & $\begin{array}{l}\text { Various pathogens } \\
\text { Gram-positive bacteria } \\
\text { Gram-positive bacteria } \\
\text { Mycobacteria } \\
\text { Staphylococcus epidermidis } \\
\text { Trypanosoma cruzi } \\
\text { Treponema maltophilia } \\
\text { Neisseria } \\
\text { Leptospira interrogans } \\
\text { Porphyromonas gingivalis } \\
\text { Fungi } \\
\text { Host } \\
\text { Host } \\
\text { Host } \\
\text { Host } \\
\text { Host }\end{array}$ \\
\hline TLR2-6 & FSL1, MALP2, Pam2CSK4 & Diacyl lipopeptides & Mycoplasma \\
\hline TLR2-4 & & $\begin{array}{l}\text { HMGB1 } \\
\text { Biglycan }\end{array}$ & $\begin{array}{l}\text { Host } \\
\text { Host }\end{array}$ \\
\hline TLR4 & & $\begin{array}{l}\text { Lipopolysaccharide } \\
\text { Taxol } \\
\text { Fusion protein } \\
\text { Envelope protein } \\
\text { ? } \\
\text { HSP } 60 \\
\text { HSP } 70 \\
\text { Type III repeat extra domain A of fibronectin } \\
\text { Oligosaccharides of hyaluronic acid } \\
\text { Polysaccharide fragments of heparan sulfate } \\
\text { Fibrinogen } \\
\text { Necrotic or dying cells } \\
\text { MRP-8/14 } \\
\text { F-EDA } \\
\text { Hyaluronan } \\
\text { Tenascin-C } \\
\text { mmLDL } \\
\text { OxPAPC } \\
\text { OxLDL } \\
\text { AGE-LDL } \\
\text { Surfactant protein A } \\
\text { b-Defensin }\end{array}$ & $\begin{array}{l}\text { Gram-negative bacteria } \\
\text { Plants } \\
\text { Respiratory syncytial virus } \\
\text { Mouse mammary-tumor virus } \\
\text { Chlamydia pneumoniae } \\
\text { Host } \\
\text { Host } \\
\text { Host } \\
\text { Host } \\
\text { Host } \\
\text { Host } \\
\text { Host } \\
\text { Host } \\
\text { Host } \\
\text { Host } \\
\text { Host } \\
\text { Host } \\
\text { Host } \\
\text { Host } \\
\text { Host } \\
\text { Host } \\
\text { Host }\end{array}$ \\
\hline TLR6 & & $\begin{array}{l}\text { Diacyl lipopeptides } \\
\text { Lipoteichoic acid } \\
\text { Zymosan }\end{array}$ & $\begin{array}{l}\text { Mycoplasma } \\
\text { Gram-positive bacteria } \\
\text { Fungi }\end{array}$ \\
\hline TLR9 & CpG-A, CpG-B, CpG-C ODNs & CpG DNA & Bacteria \\
\hline
\end{tabular}

AGE-LDL, advanced glycation end-product of low-density-lipoprotein; F-EDA, extra domain A of fibronectin; HSP, heat-shock protein; mmLDL, minimally modified low density lipoprotein; MRP, myeloid-related protein; OxLDL, oxidized low-density lipoprotein; OxPAPC, oxidation products of 1-palmitoyl-2-arachidonoyl-sn-glycerol-2phosphatidylcholine; ?, unknown.

Of particular note, platelets exert direct microbicidal activity and they can also secrete microbicidal peptides/ proteins, such as thrombocidin-1, thrombocidin-2, platelet microbicidal protein-1 (PMP-1) and $\beta$-defensin 1, among others [10]. Platelets may contribute indirectly to microbe destruction by transporting surface-bound immune complexes or complement fractions or Igs with antibody activity. Moreover, platelets facilitate the 
antimicrobial activity of neutrophils [20] and macrophages [6]. Antimicrobial peptides and proteins can also aid or complement mechanisms used by platelets to eradicate infectious pathogens. For instance, Staphylococcus aureus uses two clumping factors (Clf A and Clf B), two fibronectin-binding proteins (Fnbp A and Fnbp B), protein A, and SSL5, and it binds antibody and complement. Consequently, this bacterium is well equipped to interact with platelets under both static and shear conditions and to trigger platelet activation as a result [11].

\section{Expression of PRRs - in particular TLRs - on and in platelets is still puzzling: a path for a clue?}

The presence of TLRs - and possibly of other danger sensors - on and in platelets is indeed intriguing, as those PRRs, despite their capacity of linking a variety of PAMPs, are paramount in sensing blood borne infectious pathogens, such as bacteria and viruses. The relationship between bacteria and platelets is extremely complex; platelets secrete antibacterial products but bacterial invasion and sepsis in turn severely impair platelet production, availability and functioning. However, platelets - which are by definition essentially circulating cells - are not aimed at being sentinels of immunity as may be immature dendritic cells, for example, positioned at entry points of pathogens into the organism; why are platelets thus equipped with such a well formed apparatus for sensing pathogens [22]? Perhaps an interesting path resides in the relationship of platelets with bacteria in the oral cavity. Of interesting note, autologous platelets are now used in surgery wounds by many dentists in order to prevent excess bleeding during dental avulsion, and dentists report decreased levels of infection (A Nurden, personal communication). On the one hand, platelets in breached oral mucosae and on exposed vascular endothelia are exquisitely reactive to bacteria sensing as we (and others [11,23]) have reported. On the other hand, as bacteria are extremely frequent in the oral cavity and can inflict severe damage to organs in cases of dental-originating bacteriemia [24,25], one can wonder as to whether this interaction between platelets and bacteria in the oral cavity is truly beneficial to the host; this question remains to be investigated.

\section{Platelets can ingest a variety of pathogens and interact with phagocytic cells \\ Platelets and infectious pathogens inside}

Early observations revealed that platelets can harbor infectious pathogens (viruses [26], bacteria [10], and parasites [27]) on their surface, using CRs, FcRs for Igs and TLRs $[19,25,28]$. Other receptors bind HIV (CLEC-2, CXCR4 and DC-Sign), HCV (GPVI), and Coxsackie adenovirus [11,26]. Furthermore, platelets can engulf infectious pathogens: HIV [26] and bacteria [11] have been found inside platelets [26,29]. Even passive pathogen entry is now acknowledged as necessitating molecular and mutual interactions. Phagocytosis of antibodyopsonized particles is primarily mediated by the actinbased cytoskeleton and is a dynamic process involving a complex mix of proteins, including actin, Arp2/3 complex, Rho-family GTPases, filament-capping proteins, tropomyosin, Rho kinase, and myosin II [30].

\section{Hypotheses on infectious pathogen entry inside platelets}

The precise mechanism(s) of pathogen engulfment within platelets is not yet known, but may be nonclassical phagocytosis as platelets do not contain a complete phagosome ultrastructure, although they possess important and crucial factors such as syk [30] and extracellular Fc $\gamma$ RIIa, a molecule with an intracellular immunoreceptor tyrosine-based activation motif (ITAM) that is important for immune complex clearance [31]. Platelets can increase phagocytosis of periodontal pathogens by neutrophils, and may directly engulf bacteria such as Porphyromonas gingivalis and S. aureus [29]. While challenging for microbiologists, this discovery is extremely stimulating for cell biologists, as it highlights that a mechanism of entry is involved that may be selective, since not all types of virus or bacterium have been observed within platelets.

Therefore, it is important to study further the infectivity of pathogens within platelets. On the one hand, platelet engulfment of pathogens may not result in bacterial killing, because platelet vacuoles lack structures for killing; on the other hand, however, engulfment may succeed in bacterial killing since - upon activation - platelets can release $\beta$-defensins that have an antimicrobial effect. Last, engulfment of bacteria by platelets may enable pathogens to escape immune surveillance.

\section{Platelet and engulfment of infectious pathogens: what next?}

The destiny of engulfed microbes within platelets remains unclear: it may be different depending on the specific pathogen or the microbe's intrinsic properties, such as infectivity. When a microbe is ingested by a phagocytic cell, there are several possible outcomes for the microbe, the four main possibilities being: i) it is destroyed or lysed; ii) it is embedded within the structure like in a sanctuary, where it is hidden or protected from external defense elements; iii) it is not destroyed but to the contrary develops, with two sub-options - its development is limited to the host cell containment capacity or it exceeds the host cell capacity and bursts out, freeing the newly formed infectious pathogens that are ready to carry on invading new host cells and so on (until a negative signal for multiplication is given); iv) it behaves as a Trojan horse, modifying the host cell in such a 
manner that it acts as a carrier to transport the invader to immune sites or other compartments [10,11,24,25,28, 32-34]. None of these options has been demonstrated thus far in platelets infected by parasites, bacteria or viruses. The presence of infectious pathogens within platelets thus remains a mystery; no role for propagating viruses such as HIV has been identified so far, while platelets and HIV clearly have mutual interactions and platelets participate in HIV-induced pathology [35]. Thus, stricto sensu, platelets do not appear to be fully competent for phagocytosis and their trapping of infectious pathogens remains unsolved.

\section{Platelet assistance to neutrophils: neutrophil extracellular traps}

Platelets can aid phagocytosis by professional leukocytes. Interestingly, platelets can help the formation of neutrophil extracellular traps (NETs) that link inflammation and thrombosis (NETs contribute to thrombus formation by interacting with platelets) [36]. Clark and colleagues [37] described a mechanism of platelet-neutrophil interactions leading to improved bacterial trapping, in which activated platelets adhered to immobilized neutrophils in a model of endotoxemia and sepsis. The cell-cell mechanism involved may depend upon the properties of platelets because platelet cell fixation modified plateletneutrophil interactions. While some groups hypothesized that this type of platelet-neutrophil interaction depended in part on LPS-induced platelet activation via platelet TLR4 expression [36,37], others claimed no evidence of direct TLR4 platelet activation $[7,8]$, in contrast to TLR2 [38] or TLR9 [16,17] platelet activation. NETs catch platelets and maintain their aggregation, indicating they are substrates for platelet adhesion and that they provide stimuli for platelet activation. Platelets may bind to NETs directly or indirectly. Purified histones associate with the platelet surface in vitro, particularly via TLRs $[39,40]$. Platelets also bind double- and single-stranded DNA in vitro [39]. Interactions of NETs with platelets may lead to a vicious loop of NET formation and platelet activation, because platelets, if pre-stimulated with LPS or collagen, induce NET release by neutrophils [37]. Despite controversy regarding the role of platelet TLR4/MD2 activation by LPS, bacterial residues might induce the binding of platelets to adherent neutrophils in pulmonary sinusoids, and cause sustained neutrophil activation and NET formation. Indeed, LPS, even at high concentrations, is unable to induce NET formation directly from neutrophils, suggesting that platelets are necessary for rapid LPS-induced neutrophil NET formation. In addition, several investigators have demonstrated that neutrophilinduced NET formation can occur in response to LPS and other agonists in the absence of platelets [41]. NETs contain proteolytic activity that can trap and kill microbes in tissues [37]. Furthermore, platelets and polymorphonuclear leukocytes interact in dynamic conditions. Formation of close interactions between neutrophils and platelets, a condition necessary for active phagocytosis, is expanded under inflammatory conditions, in which platelets participate substantially [21]. Formation of a synapse between neutrophils and platelets, a requirement for effective phagocytosis, is magnified under inflammatory conditions, where platelets undergo substantial and persistent activation [42].

\section{Platelets secrete molecules that regulate inflammation}

Platelet association with a panoply of biological response modifiers

Platelets are characterized in part by their association with a large number of molecules (Table 2), of which more than 300 are secreted. However, these data should be interpreted with caution, as platelet molecules may originate from three sources: i) inherited from lineage cells (megakaryocyte); ii) absorbed from the environment; iii) secreted de novo (a recently identified puzzling issue that is unexpected in non-nucleated cells devoid of nucleic acid and DNA, except mitochondrial DNA and RNA absorbed from lysed cells such as tumor cells) $[6,19]$. Consequently, the number of molecules of platelet origin and the repertoire of proteins present on platelet membranes is debatable. Activation processes allow the recruitment of molecules onto the cell surface (P-selectin or CD62P is initially located intracellularly within the $\alpha$ granule) [43]. Conversely, many molecules are internalized during activation or shed in membrane-derived microparticles (MPs). Thus, during activation there is a change in platelet phenotype with the appearance of novel molecules and disappearance of others, some changes being transient and others permanent. During activation, proteins/glycoproteins can be proteolytically cleaved from the cell surface. However, this shedding process is distinct from secretion, resulting from mobilization of molecules from storage granules with or without transient expression at the surface (as for sCD40L and sCD62P).

\section{The secretion activity of platelets}

In the circulation, each platelet contains about $35 \alpha$ granules and 5 dense bodies. $\alpha$ Granules enclose an array of immunomodulatory soluble factors, comprising important chemokines, such as platelet factor-4 (PF4; CXCL4), $\beta$-thromboglobulin ( $\beta$-TG; an isoform of CXCL7), regulated upon activation normal $\mathrm{T}$ cell expressed and secreted (RANTES; CCL5), and macrophage inflammatory protein-1- $\alpha$ (MIP-1 $\alpha$; CCL3) (Table 2). All these molecules have major roles in many fields of innate immunity. 
Table 2. Diversity of proposed platelet-associated molecules with known immune functions

\begin{tabular}{|c|c|c|c|c|}
\hline Molecule & Classification & Functions & Cellular targets & Reference \\
\hline ADAM10 (CDw156c) & Enzyme - protease & $\begin{array}{l}\text { Shedding of surface receptors in } \\
\text { platelets }\end{array}$ & $\begin{array}{l}\text { Platelet, B-cells, malignant cell types, } \\
\text { endothelial cells }\end{array}$ & PMID:20644114 \\
\hline ADAM17 (CD156b) & Enzyme - protease & $\begin{array}{l}\text { Shedding of surface receptors in } \\
\text { platelets }\end{array}$ & Platelets & PMID:20644114 \\
\hline ADAMTS13 & Enzyme - protease & (Sub)endothelial VWF cleavage & Platelets, endothelial cells & PMID:19389207 \\
\hline Angiogenin & Enzyme - RNAse & Angiogenesis & Endothelial cells & PMID:18279456 \\
\hline Angiopoietin-1 & Growth factor & Angiopoiesis & Endothelial cells & PMID:22071944 \\
\hline $\begin{array}{l}\text { Angiopoietin-related } \\
\text { growth factor }\end{array}$ & Growth factor & Angiopoiesis & Endothelial cells & PMID:22071944 \\
\hline Angiostatin & Enzyme - protease & Angiogenesis & Endothelial cells & PMID:22512504 \\
\hline Basigin & Enzyme - protease & $\begin{array}{l}\text { Spermatogenesis (P. falciparum } \\
\text { binding) }\end{array}$ & $\begin{array}{l}\text { Epithelial cells, endothelial cells, } \\
\text { leukocytes, erythrocytes }\end{array}$ & PMID:21320284 \\
\hline BDNF & Growth factor & Neurogenesis & Neurons & PMID:15585351 \\
\hline Beta-thromboglobulin & Chemokine & Chemotaxis & Fibroblasts, neutrophils & PMID:11138777 \\
\hline bFGF & Growth factors & Angiogenesis & Fibroblasts, endothelial cells & PMID:21142700 \\
\hline BMP2 & Cytokine & Osteogenesis & Osteoblast & PMID:22808271 \\
\hline BMP6 & Cytokine & Osteogenesis & Mesenchymal stem cells & PMID:19413738 \\
\hline CCL17 & Chemokine & Chemotaxis & T cells & PMID:18723831 \\
\hline CCL3 (also known as PF4) & Chemokine & Chemotaxis and angiogenesis & Monocytes, neutrophils & PMID:12851650 \\
\hline CCL4 & Chemokine & Chemotaxis & Natural killer cells, monocytes, leukocytes & PMID:12851650 \\
\hline CCL5 & Chemokine & Chemotaxis & T cells, eosinophils, basophils, leukocytes & PMID:12851650 \\
\hline CCL7 & Chemokine & Chemotaxis & Monocytes, macrophages & PMID:12851650 \\
\hline CRP & Inflammatory marker & $\begin{array}{l}\text { Modulator of innate and adaptive } \\
\text { immunity }\end{array}$ & $\begin{array}{l}\text { Endothelial cells, platelets, polymorpho- } \\
\text { nuclear leukocytes, monocytes }\end{array}$ & PMID:15492312 \\
\hline CTGF & Growth factor & Angiogenesis & $\begin{array}{l}\text { Endothelial cells, fibroblasts, } \\
\text { monocytes, chondrocyte }\end{array}$ & PMID:15598883 \\
\hline CXCL4 & Chemokine & Angiogenesis & $\begin{array}{l}\text { Neutrophils, monocytes, endothelial } \\
\text { cells, fibroblasts }\end{array}$ & PMID:1718005 \\
\hline CXCL5 & Chemokine & Chemotaxis & Neutrophils, epithelial cells & PMID:12851650 \\
\hline CXCL7 & Chemokine & Chemotaxis & Fibroblasts, neutrophils, monocytes & PMID:18723831 \\
\hline EGF & Growth factor & Chemotaxis & Epidermal cells, epithelial cells, fibroblasts & PMID:1572403 \\
\hline Endostatin & Cytokine & Mitogen & Endothelial cells & PMID:21680800 \\
\hline $\begin{array}{l}\text { Endothelial cell-selective } \\
\text { adhesion molecule }\end{array}$ & $\begin{array}{l}\text { Immunoglobulin } \\
\text { superfamily }\end{array}$ & Angiogenesis & Neutrophils, monocytes, endothelial cells & PMID:17723134 \\
\hline Gas-6 & Growth factor & Angiogenesis & $\begin{array}{l}\text { Vascular smooth muscle cells, } \\
\text { endothelial cells }\end{array}$ & PMID:10648841 \\
\hline HMGB1 & Cytokine & Angiogenesis & $\begin{array}{l}\text { Neutrophil, monocytes, dendritic cells, } \\
\text { macrophages }\end{array}$ & PMID:11154118 \\
\hline IGFBP3 & Growth factor & $\begin{array}{l}\text { Modulator of innate and adaptive } \\
\text { immunity }\end{array}$ & Fibroblasts & PMID:7679986 \\
\hline $\mid L-1-a$ & Cytokine & $\begin{array}{l}\text { Modulator of innate and adaptive } \\
\text { immunity and angiogenesis }\end{array}$ & $\begin{array}{l}\text { Endothelial cells, dendritic cells, } \\
\text { monocytes, macrophages, B and T cells }\end{array}$ & PMID:7631154 \\
\hline $\mid L-1-\beta$ & Cytokine & $\begin{array}{l}\text { Modulator of innate and adaptive } \\
\text { immunity and angiogenesis }\end{array}$ & $\begin{array}{l}\text { Endothelial cells, dendritic cells, } \\
\text { monocytes, macrophages, B and T cells }\end{array}$ & PMID:7631154 \\
\hline IL-7 & Cytokine & $\begin{array}{l}\text { Modulator of innate and adaptive } \\
\text { immunity }\end{array}$ & $\begin{array}{l}\text { T and B cells, natural killer cells, } \\
\text { macrophages, monocytes }\end{array}$ & PMID:12742982 \\
\hline |L-8 & Chemokine & $\begin{array}{l}\text { Modulator of innate and adaptive } \\
\text { immunity }\end{array}$ & $\begin{array}{l}\text { Neutrophils, B cells, endothelial cells, } \\
\text { macrophage }\end{array}$ & PMID:14713510 \\
\hline
\end{tabular}


Table 2. Continued

\begin{tabular}{|c|c|c|c|c|}
\hline Molecule & Classification & Functions & Cellular targets & Reference \\
\hline Osteoprotegerin & Cytokine & $\begin{array}{l}\text { Modulator of innate and adaptive } \\
\text { immunity }\end{array}$ & Osteoclasts & PMID:14585373 \\
\hline PAl-1 & Enzyme - protease & Chemotaxis & Lymphocytes, neutrophils & PMID:17884148 \\
\hline PDGF & Growth factor & Osteogenesis & $\begin{array}{l}\text { Epithelial cells, endothelial cells, } \\
\text { smooth muscle cells, fibroblasts, } \\
\text { chondrocytes }\end{array}$ & PMID:2835772 \\
\hline Soluble CD40 ligand & Cytokine & Angiogenesis and chemotaxis & Endothelial cells & PMID:12186789 \\
\hline Soluble CD62P & Cytokine & Angiogenesis and chemotaxis & B cells, dendritic cells, platelets & PMID:9496730 \\
\hline TGF- $\beta$ & Growth factor & $\begin{array}{l}\text { Modulator of innate and adaptive } \\
\text { immunity }\end{array}$ & Neutrophils, monocytes & PMID:11012227 \\
\hline Thrombocidin-1 & $\begin{array}{l}\text { Chemokine, } \\
\text { antimicrobial factor }\end{array}$ & Cellular interaction & Epithelial cells, endothelial cells, B cells & PMID:10877842 \\
\hline Thrombocidin-2 & $\begin{array}{l}\text { Chemokine, } \\
\text { antimicrobial factor }\end{array}$ & $\begin{array}{l}\text { Modulator of innate and adaptive } \\
\text { immunity }\end{array}$ & $\begin{array}{l}\text { Bacillus subtilis, Escherichia coli, } \\
\text { Staphylococcus aureus, Lactococcus lactis, } \\
\text { fungicidal for Cryptococcus neoformans }\end{array}$ & PMID:10877842 \\
\hline Thrombospondin-1 & Cytokine & $\begin{array}{l}\text { Modulator of innate and adaptive } \\
\text { immunity }\end{array}$ & $\begin{array}{l}\text { Bacillus subtilis, Escherichia coli, } \\
\text { Staphylococcus aureus, Lactococcus lactis, } \\
\text { fungicidal for Cryptococcus neoformans }\end{array}$ & PMID:16263699 \\
\hline $\begin{array}{l}\text { Tissue inhibitor of } \\
\text { metalloproteinases-1 }\end{array}$ & Enzyme - protease & Modulator of innate immunity & $\begin{array}{l}\text { Endothelial cells, neutrophils, vascular } \\
\text { smooth muscle cells, fibroblasts }\end{array}$ & PMID:19410025 \\
\hline $\begin{array}{l}\text { Tissue inhibitor of } \\
\text { metalloproteinases-2 }\end{array}$ & Enzyme - protease & Inflammation & Keratinocytes, endothelial cells & PMID:19410025 \\
\hline $\begin{array}{l}\text { Tissue inhibitor of } \\
\text { metalloproteinases-3 }\end{array}$ & Enzyme - protease & Angiogenesis & Keratinocytes, endothelial cells & PMID:19410025 \\
\hline $\begin{array}{l}\text { Tissue inhibitor of } \\
\text { metalloproteinases-4 }\end{array}$ & Enzyme - protease & Angiogenesis & Keratinocytes, endothelial cells & PMID:19410025 \\
\hline VEGF & Growth factor & Angiogenesis & Endothelial cells & PMID:21680800 \\
\hline
\end{tabular}

ADAM, a disintegrin and metalloproteinase; ADAMTS, a disintegrin and metalloproteinase with thrombospondin motifs; BDNF, brain-derived neurotrophic factor; bFGF, basic fibroblast growth factor; BMP, bone morphogenetic protein; $\mathrm{CCL}, \mathrm{C}-\mathrm{C}$ motif ligand; $\mathrm{CRP}, \mathrm{C}$-reactive protein; $\mathrm{CTGF}$, connective tissue growth factor; CXCL, C-X-C motif ligand; EGF, epidermal growth factor; Gas-6, growth arrest-specific 6; HMGB1, high-mobility group protein B1; IGFBP3, insulin-like growth factor-binding protein 3; IL, interleukin; PAI, plasminogen activator inhibitor; PDGF, platelet derived growth factor; TGF, transforming growth factor; VEGF, vascular endothelial growth factor; VWF, von Willebrand factor.

\section{A selection of platelet secreted molecules important in immune process regulation Platelet factor-4}

PF4 prevents apoptosis of monocytes and initiates their differentiation into macrophages, induces neutrophil adhesion to non-stimulated endothelium and granulecontent release [44], favors neutrophil, monocyte, and fibroblast chemotaxis, and eosinophil adherence, induces basophil release of histamine, and controls multiple $\mathrm{T}$ cell activities, including inhibition of monocyte-dependent and CD3/CD28 antibody ligation-induced T-cell proliferation and activation. It has a complex role in the regulation of $\mathrm{T}$-cell responses (regulatory $\mathrm{T}$ cells $\left(\mathrm{CD} 4^{+} \mathrm{CD} 25^{+}\right)$and non-regulatory $\mathrm{T}$ cells $\left.\left(\mathrm{CD} 4^{+} \mathrm{CD} 25^{-}\right)\right)$ and inhibits $\mathrm{CD} 4^{+} \mathrm{CD} 25^{-} \mathrm{T}$-cell proliferation, but stimulates proliferation of $\mathrm{CD} 4{ }^{+} \mathrm{CD} 25^{+}$regulatory $\mathrm{T}$ cells [45].

\section{$\beta$-Thromboglobulin}

$\beta$-TG comprises sets of proteins, actually proteolytic products of inactive precursors, that stimulate or inhibit neutrophils, depending on their processing [46], and attract neutrophils, but not monocytes [47], in the vasculature.

\section{RANTES}

RANTES is consistently released by thrombin-stimulated platelets. It is less pleiotropic than other chemokines, but it is highly efficient in recruiting monocytes, $\mathrm{T}$ cells and eosinophils [48]. It contributes to inflammation and atheromatogenesis by recruiting circulating monocytes that bind altered microvascular and arterial endothelium by triggering shear-resistant monocyte arrest [49].

\section{Macrophage inflammatory protein-1a}

MIP-1 $\alpha$ has histamine-releasing activity for basophils and is chemotactic for T lymphocytes. It is an important mediator of virus-induced inflammation in vivo and plays a role in cellular, but not humoral, responses to coxsackie virus B3. During infection, MIP- $1 \alpha$ may be required for the efficient recruitment of $\mathrm{T}$ cells to sites of viral infection [50]. 
Thus, if platelets can secrete chemokines, the latter can exert reciprocal actions on platelets. RANTES and MIP$1 \alpha$ stimulate platelets to increase calcium signals, to aggregate, and to release granular contents.

\section{Soluble CD40 ligand}

Other cytokine- and chemokine-like molecules secreted by platelets are leading immunomodulatory agents, either in physiology or in pathology, such as CD40L $[51,52]$. The identification of CD40L as a major product, both quantitatively and qualitatively, of platelets was important because it was the first evidence that platelets abundantly secreted factors not involved in hemostasis. The role of soluble CD40L (sCD40L) in acute transfusion reactions, first in non-hemolytic febrile transfusion reactions and then in transfusion related acute lung injury, is intriguing. We and other groups established $e x$ vivo models of blood cells obtained from healthy donors to explore the extent to which intact or lysed platelets could be transfused, and investigated biological response modifiers from supernatants and determined how they affected different cell types, including B lymphocytes, $\mathrm{T}$ lymphocytes, dendritic cells, monocytes, and epithelial cells (Figure 1). The accumulation of inflammatory cytokines and chemokines during platelet component storage increased the inflammatory effects of leukocytes and endothelial cells to levels comparable to those observed during pathological conditions. We provided evidence for a role of $\mathrm{sCD} 40 \mathrm{~L}$ in acute transfusion reaction cases in which there was complete excretion of sCD40L from platelets into the supernatant such that no sCD40L was left within the platelets, in contrast to that observed in control patient samples $[53,54]$. We extended this finding to a series of other cytokines previously unassociated with platelets, IL-27 and OX40L [55].

\section{Microparticles at the interface of procoagulant activity and inflammation}

The 'microparticle' phenomenon

In 1967, Wolf described small membrane fragments referred to as 'platelet dust' that were released after platelet activation [56]. This 'platelet dust' (now acknowledged as MPs) retain procoagulant activity similar to activated platelets [56]. MPs of various cell types have been detected in circulating blood [57,58], including from leukocytes, erythrocytes, endothelial cells and platelets. The most abundant circulating MPs are platelet-derived MPs, less than $1.0 \mu \mathrm{m}$ in diameter, which represent approximately 70 to $90 \%$ of all circulating MPs [59]. The stimulation and activation of each cell type can induce increased levels of cytoplasmic calcium associated with the translocation of phosphatidylserine and phosphatidylethanolamine from the inner to the outer leaflet of the cell membrane and activation of calpain, which facilitates MP shedding by cleaving cytoskeletal filaments [60]. MPs are involved in ischemic stroke, metastasis, tumor development, and inflammatory and neurodegenerative diseases [60].

\section{Platelet microparticles}

Platelet MPs are membrane vesicles shed by platelets after activation that transports platelet molecules (glycoprotein IIb/IIIa, Ib and P-selectin). The interface between blood cells and arterial vessel walls determines the progression of atherosclerotic plaques and thrombotic complications [61]. Evidence suggests a role of activated platelets and platelet-derived MPs in disease development by interaction with leukocytes, endothelial cells and smooth muscle cells [62]. During inflammation, plateletderived MPs can activate antigen-presenting cells, modulate dendritic cell activation, increase $\mathrm{T}$-cell responses, induce B-cell production of IgG antibodies, and enhance germinal center formation in cooperation with $\mathrm{T}$ cells [60].

\section{The role of platelets in sepsis}

\section{Sepsis is frequently associated with unexplained} thrombocytopenia

Sepsis provides an interesting model for deciphering the role of platelets beyond hemostatic functions. Thrombocytopenia is a frequent occurrence in sepsis, implying platelets are involved in the pathophysiology $[63,64]$. Generally, platelet counts in sepsis patients markedly decrease during the first 4 days [65]. Conversely, sepsis is a significant risk factor for thrombocytopenia in critically ill patients, and the severity of sepsis correlates with decreased platelet counts [66]. During bacterial infection, direct interactions between platelets and bacteria, leading to enhanced macrophagy [67], may contribute to thrombocytopenia. Platelet TLR4 was found to lead to neutrophil-dependent pulmonary sequestration in response to LPS [8]. Interestingly, they demonstrated the in vivo formation of platelet aggregates in response to LPS [68]. However, mechanisms that may link impaired central platelet production and peripheral overconsumption and/or destruction are poorly understood.

\section{Hypotheses for sepsis-associated thrombocytopenia: the coagulation path}

Platelet consumption may also be important in patients with sepsis because of their activation and subsequent sequestration on endothelium or increased binding to circulating neutrophils [69]. Platelet adhesion to capillaries requires NADPH oxidase, inducible nitric oxide synthase, P-selectin and activated coagulation (platelet adhesion, fibrin deposition, and blood flow stoppage in capillaries) [70]. In addition to endotoxin and inflammatory cytokines, the ongoing generation of thrombin (a 


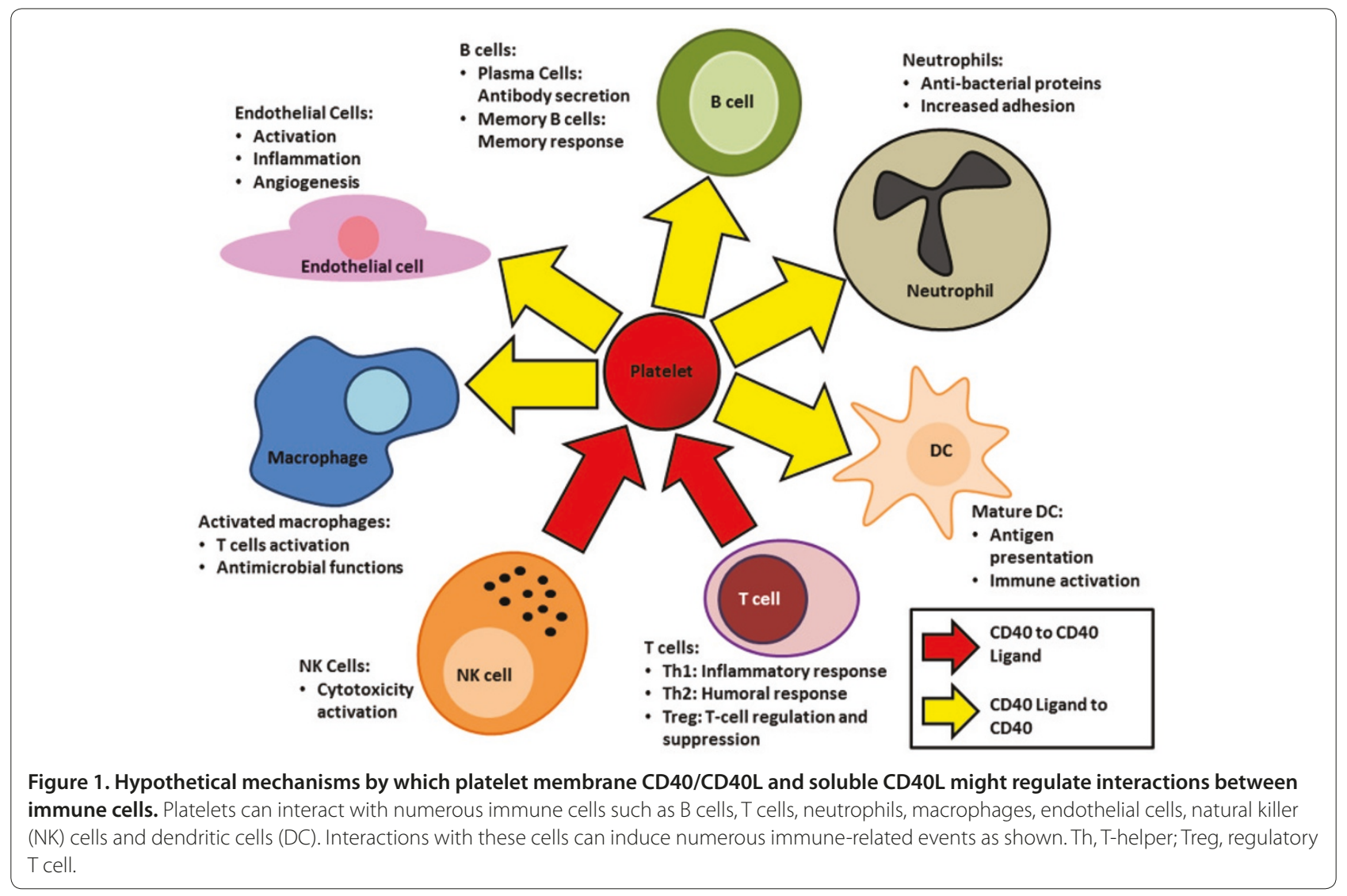

potent activator of platelets in vivo) and the release of platelet activating factor activates platelets. The contribution of platelet activating factor in sepsis was demonstrated in animal models [71], although targeted therapeutic interventions to antagonize it led to disappointing results in human sepsis [72]. Coagulation is closely associated with severe systemic inflammatory responses occurring in sepsis patients [73], but therapeutic approaches targeting coagulation that were beneficial in animal models were generally unsuccessful in humans.

\section{Further hypotheses for sepsis-associated thrombocytopenia: the inflammatory path}

Intriguingly, decreased plasma levels of RANTES seem to parallel thrombocytopenia [74]. Besides this, tissue factor, a prominent product of platelets $[75,76]$ and activated monocytes [77], functions in coagulation and inflammation by exposing procoagulant phospholipid binding sites for factors Va and Xa. Thrombospondin-1 contributed to mortality in experimental models [78]. Of note, there is a balance between levels of pro- and antiinflammatory cytokines (the latter lead to a so-called cytokine storm). Transforming growth factor- $\beta 1$ is an important counter-regulatory, anti-inflammatory cytokine in sepsis and represents a prime candidate for factors that mediate sepsis resolution; it also prevents leukocyte apoptosis [79].

\section{Conclusion}

Platelets are thought to sense danger by recognizing subendothelial molecules following vascular endothelium damage, and following activation they engage repair systems by secreting appropriate adhesion and healing molecules. Platelets can sense other forms of danger, in particular those that are infectious in nature as they express numerous specialized (TLRs) and less specialized but highly functional receptors (FCR for Igs/antibodies and complement factor receptors). Platelets can be activated by infectious pathogen moieties and by immune complexes formed around infectious pathogens. The nature of the infectious danger activates platelets, directing them to secrete specific biological response modifiers comprising cytokine and chemokine-like molecules. Platelets also engage membrane and secreted factors that interact with neighboring and distant immune cells to eliminate immune complexes, characteristic of innate immunity. These complex responses might even alter adaptive immune responses, at least in experimental models. During sepsis syndrome, platelets 
are particularly mobilized along a spectrum ranging from hyperactivation to exhaustion, and this may be an attractive target for new drug treatment approaches, once the finely tuned mechanisms are identified.

\section{Abbreviations}

CD40L, CD40-ligand; IL, interleukin; LPS, lipopolysaccharide; MIP, macrophage inflammatory protein; MP, microparticle; NET, neutrophil extracellular trap; PAMP, pathogen-associated molecular pattern; PF, platelet factor; PRR, pathogen recognition receptor; RANTES, regulated upon activation normal T cell expressed and secreted; sCD40L, soluble CD40 ligand; TG, thromboglobulin; TLR, Toll-like receptor.

\section{Competing interests}

The authors declare that they have no competing interests.

\section{Acknowledgements}

The authors would like to acknowledge the excellent scientific and technical skills of present and former collaborators and PhD students whose contributions have been cited in this work. They are grateful to: Drs P Chavarin and J Berthet, to Ms P Damien, KA Nguyen, MA Eyraud and to Mr CA Arthaud (The Platelet Immunology Team at the Mixed Research Unit of EFS and University Jean-Monnet, Saint-Etienne). This study was supported (in part) by research funding from EFS Auvergne-Loire, the French Agence Nationale de la Recherche (ANR) under reference ANR-12- JSV1 and the Agence Nationale de la Sécurité et du Médicament et des produits de santé (ANSM - AAP-2012-011, reference 2012S055) to Professor O Garraud.

\section{Author details}

'Université de Lyon, GIMAP, EA3064, F-42023-A, Saint Etienne, France. 'EFS Auvergne-Loire and GIMAP-EA 3064, Université de Saint-Etienne, Faculté de Médecine, 15 rue Ambroise Paré, 42023 Saint-Etienne cedex 2, France. ${ }^{3}$ Unit Cytokines \& Inflammation, Institut Pasteur, Paris 75015, France.

\section{Published: 27 August 2013}

\section{References}

1. Fong KP, Barry C, Tran AN, Traxler EA, Wannemacher KM, Tang HY, Speicher KD, Blair IA, Speicher DW, Grosser T, Brass LF: Deciphering the human platelet sheddome. Blood 2011, 117:e15-26.

2. Vivier E, Raulet DH, Moretta A, Caligiuri MA, Zitvogel L, Lanier LL, Yokoyama WM, Ugolini S: Innate or adaptive immunity? The example of natural killer cells. Science 2011, 331:44-49.

3. Hawiger J, Hawiger A, Timmons S: Endotoxin-sensitive membrane component of human platelets. Nature 1975, 256:125-127.

4. Morrison DC, Oades ZG: Mechanisms of lipopolysaccharide-initiated rabbit platelet responses. II. Evidence that lipid $A$ is responsible for binding of lipopolysaccharide to the platelet. J Immuno/ 1979, 122:753-758.

5. Cognasse F, Hamzeh H, Chavarin P, Acquart S, Genin C, Garraud O: Evidence of Toll-like receptor molecules on human platelets. Immunol Cell Biol 2005, 83:196-198

6. Semple JW, Italiano JE Jr, Freedman J: Platelets and the immune continuum. Nat Rev Immunol 2011, 11:264-274.

7. Aslam R, Speck ER, Kim M, Crow AR, Bang KW, Nestel FP, Ni H, Lazarus AH, Freedman J, Semple JW: Platelet Toll-like receptor expression modulates lipopolysaccharide-induced thrombocytopenia and tumor necrosis factor-alpha production in vivo. Blood 2006, 107:637-641.

8. Andonegui G, Kerfoot SM, McNagny K, Ebbert KV, Patel KD, Kubes P: Platelets express functional Toll-like receptor-4. Blood 2005, 106:2417-2423.

9. Berthet J, Damien P, Hamzeh-Cognasse H, Arthaud CA, Eyraud MA, Zeni F, Pozzetto B, McNicol A, Garraud O, Cognasse F: Human platelets can discriminate between various bacterial LPS isoforms via TLR4 signaling and differential cytokine secretion. Clin Immuno/ 2012, 145:189-200.

10. Yeaman MR: Platelets in defense against bacterial pathogens. Cell Mol Life Sci 2010, 67:525-544

11. Cox D, Kerrigan SW, Watson SP: Platelets and the innate immune system: mechanisms of bacterial-induced platelet activation. J Thromb Haemost 2011, 9:1097-1107.

12. McNicol A, Agpalza A, Jackson EC, Hamzeh-Cognasse H, Garraud O, Cognasse F: Streptococcus sanguinis-induced cytokine release from platelets.
J Thromb Haemost 2011, 9:2038-2049

13. Wei-Fan Chen, Jie-Jen Lee, Chao-Chien Chang, Kuan-Hong Lin, Shwu-Huey Wang and Joen-Rong Sheu: Platelet protease-activated receptor (PAR) 4, but not PAR1, associated with neutral sphingomyelinase responsible for thrombin-stimulated ceramide-NF-kB signaling in human platelets. Haematologica 2013, 98:793-801.

14. Panzer S: Differential response to LPS isotypes induced platelet activation mediated by Toll-like receptor (TLR)-4. Clin Immunol 2013, 146:13-14.

15. Risitano A, Beaulieu LM, Vitseva O, Freedman JE: Platelets and platelet-like particles mediate intercellular RNA transfer. Blood 2012, 119:6288-6295.

16. Panigrahi S, Ma Y, Hong L, Gao D, West XZ, Salomon RG, Byzova TV, Podrez EA Engagement of platelet Toll-like receptor 9 by novel endogenous ligands promotes platelet hyper-reactivity and thrombosis. Circ Res 2012, 112:103-112.

17. Thon JN, Peters CG, Machlus KR, Aslam R, Rowley J, Macleod H, Devine MT, Fuchs TA, Weyrich AS, Semple JW, Flaumenhaft R, Italiano JE Jr: T granules in human platelets function in TLR9 organization and signaling. $J$ Cell Biol 2012, 198:561-574.

18. Cognasse F, Hamzeh-Cognasse H, Berthet J, Damien P, Lucht F, Pozzetto B, Garraud O: Altered release of regulated upon activation, normal T-cell expressed and secreted protein from human, normal platelets: contribution of distinct HIV-1MN gp41 peptides. AIDS 2009, 23:2057-2059.

19. Garraud O, Berthet J, Hamzeh-Cognasse H, Cognasse F: Pathogen sensing, subsequent signalling, and signalosome in human platelets. Thromb Res 2011, 127:283-286

20. Weyrich AS, Zimmerman GA: Platelets: signaling cells in the immune continuum. Trends Immunol 2004, 25:489-495.

21. Assinger A, Laky M, Schabbauer G, Hirschl AM, Buchberger E, Binder BR, Volf I: Efficient phagocytosis of periodontopathogens by neutrophils requires plasma factors, platelets and TLR2. J Thromb Haemost 2011, 9:799-809.

22. Cognasse F, Garraud O: Human platelets exhibit infectious -pathogenbinding ligands and participate to inflammation (and more ?). Exp Hematol 2005, 33:1081-1082.

23. McNicol A, Israels SJ: Mechanisms of oral bacteria-induced platelet activation. Can J Physiol Pharmacol 2010, 88:510-524.

24. Fitzgerald JR, Foster TJ, Cox D: The interaction of bacterial pathogens with platelets. Nat Rev Microbiol 2006, 4:445-457.

25. Cox D: Bacteria-platelet interactions. J Thromb Haemost 2009, 7:1865-1866.

26. Flaujac C, Boukour S, Cramer-Borde E: Platelets and viruses: an ambivalent relationship. Cell Mol Life Sci 2010, 67:545-556.

27. Pleass RJ: Platelet power: sticky problems for sticky parasites? Trend Parasitol 2009, 25:296-299.

28. Yeaman MR: Bacterial-platelet interactions: virulence meets host defense. Future Microbio/ 2010, 5:471-506.

29. Youssefian T, Drouin A, Masse JM, Guichard J, Cramer EM: Host defense role of platelets: engulfment of HIV and Staphylococcus aureus occurs in a specific subcellular compartment and is enhanced by platelet activation. Blood 2002, 99:4021-4029

30. Aslam R, Kim M, Speck ER, Seetanah AC, Molinski S, Freedman J, Semple JW: Platelet and red blood cell phagocytosis kinetics are differentially controlled by phosphatase activity within mononuclear cells. Transfusion 2007, 47:2161-2168.

31. Huang ZY, Chien P, Indik ZK, Schreiber AD: Human platelet FcgammaRIIA and phagocytes in immune-complex clearance. Mol Immunol 2011, 48:691-696.

32. Klinger $\mathrm{MH}$, Jelkmann W: Role of blood platelets in infection and inflammation. J Interferon Cytokine Res 2002, 22:913-922.

33. Beaulieu LM, Freedman JE: The role of inflammation in regulating platelet production and function: Toll-like receptors in platelets and megakaryocytes. Thrombosis Res 2010, 125:205-209.

34. Kerrigan SW, Cox D: Platelet-bacterial interactions. Cell Mol Life Sci 2010 67:513-523.

35. Damien P, Cognasse F, Lucht F, Suy F, Pozzetto B, Garraud O, HamzehCognasse H: HAART alters inflammation linked to platelet cytokines in HIV-1 infected patients. J Infect Dis 2013, in press.

36. Ma AC, Kubes P: Platelets, neutrophils, and neutrophil extracellular traps (NETs) in sepsis. J Thromb Haemost 2008, 6:415-420.

37. Clark SR, Ma AC, Tavener SA, McDonald B, Goodarzi Z, Kelly MM, Patel KD, Chakrabarti S, McAvoy E, Sinclair GD, Keys EM, Allen-Vercoe E, Devinney R, Doig CJ, Green FH, Kubes P: Platelet TLR4 activates neutrophil extracellular traps to ensnare bacteria in septic blood. Nat Med 2007, 13:463-469. 
38. Kalvegren $\mathrm{H}$, Skoglund C, Helldahl C, Lerm M, Grenegard M, Bengtsson T: Toll-like receptor 2 stimulation of platelets is mediated by purinergic P2X1-dependent Ca2+ mobilisation, cyclooxygenase and purinergic P2Y1 and P2Y12 receptor activation. Thromb Haemost 2010, 103:398-407.

39. Fuchs TA, Brill A, Wagner DD: Neutrophil extracellular trap (NET) impact on deep vein thrombosis. Arterioscler Thromb Vasc Biol 2012, 32:1777-1783.

40. Semeraro F, Ammollo CT, Morrissey JH, Dale GL, Friese P, Esmon NL, Esmon $\mathrm{CT}$ : Extracellular histones promote thrombin generation through plateletdependent mechanisms: involvement of platelet TLR2 and TLR4. Blood 2011, 118:1952-1961

41. Yost CC, Cody MJ, Harris ES, Thornton NL, McInturff AM, Martinez ML, Chandler NB, Rodesch CK, Albertine KH, Petti CA, Weyrich AS, Zimmerman GA: Impaired neutrophil extracellular trap (NET) formation: a novel innate immune deficiency of human neonates. Blood 2009, 113:6419-6427.

42. Manfredi AA, Rovere-Querini P, Maugeri N: Dangerous connections: neutrophils and the phagocytic clearance of activated platelets. Curr Opin Hematol 2010, 17:3-8.

43. Whiteheart SW: Platelet granules: surprise packages. Blood 2011, 118:1190-1191.

44. Petersen F, Bock L, Flad HD, Brandt E: Platelet factor 4-induced neutrophilendothelial cell interaction: involvement of mechanisms and functional consequences different from those elicited by interleukin-8. Blood 1999, 94:4020-4028

45. Liu K, Liang C, Liang Z, Tus K, Wakeland EK: Sle1ab mediates the aberrant activation of STAT3 and Ras-ERK signaling pathways in B lymphocytes. $\mathrm{J}$ Immuno/ 2005, 174:1630-1637.

46. Brandt E, Petersen F, Ludwig A, Ehlert JE, Bock L, Flad HD: The betathromboglobulins and platelet factor 4: blood platelet-derived CXC chemokines with divergent roles in early neutrophil regulation. J Leukocyte Biol 2000, 67:471-478.

47. Ravindran R, Krishnan LK: A biochemical study on the effect of proteolysis of beta-thromboglobulin proteins released from activated platelets on fibroblast proliferation. Pathophysiol Haemost Thromb 2007, 36:285-289.

48. Levy JA: The unexpected pleiotropic activities of RANTES. J Immuno/ 2009, 182:3945-3946.

49. Lehner T: The role of CCR5 chemokine ligands and antibodies to CCR5 coreceptors in preventing HIV infection. Trends Immuno/ 2002, 23:347-351.

50. McDermott DH, Murphy PM: Chemokines and their receptors in infectious disease. Springer Sem Immunopathol 2000, 22:393-415.

51. Andre P, Nannizzi-Alaimo L, Prasad SK, Phillips DR: Platelet-derived CD40L: the switch-hitting player of cardiovascular disease. Circulation 2002 106:896-899.

52. Phipps RP, Kaufman J, Blumberg N: Platelet derived CD154 (CD40 ligand) and febrile responses to transfusion. Lancet 2001, 357:2023-2024.

53. Cognasse F, Osselaer JC, Payrat JM, Chavarin P, Corash L, Garraud O: Release of immune modulation factors from platelet concentrates during storage after photochemical pathogen inactivation treatment. Transfusion 2008, 48:809-813.

54. Cognasse F, Boussoulade F, Chavarin P, Acquart S, Fabrigli P, Lamy B, Garraud $\mathrm{O}$ : Release of potential immunomodulatory factors during platelet storage. Transfusion 2006, 46:1184-1189.

55. Hamzeh-Cognasse H, Damien P, Nguyen KA, Zeni F, Pozzetto B, Cognasse F, Garraud O: Contribution of activated platelets to plasma IL-27 levels. Crit Care 2013, 17:411.

56. Wolf $\mathrm{P}$ : The nature and significance of platelet products in human plasma. Br J Haematol 1967, 13:269-288.

57. Boilard E, Nigrovic PA, Larabee K, Watts GF, Coblyn JS, Weinblatt ME, Massarotti EM, Remold-O'Donnell E, Farndale RW, Ware J, Lee DM: Platelets amplify inflammation in arthritis via collagen-dependent microparticle production. Science 2010, 327:580-583.

58. Italiano JE Jr, Mairuhu AT, Flaumenhaft R: Clinical relevance of microparticles from platelets and megakaryocytes. Curr Opin Hematol 2010, 17:578-584.

59. Flaumenhaft R, Dilks JR, Rozenvayn N, Monahan-Earley RA, Feng D, Dvorak AM: The actin cytoskeleton differentially regulates platelet alpha-granule and dense-granule secretion. Blood 2005, 105:3879-3887.

60. Nurden AT: Platelets, inflammation and tissue regeneration. Thromb Haemost 2011, 105 Suppl 1:S13-33.
61. Lutgens E, Lievens D, Beckers L, Donners M, Daemen M: CD40 and its ligand in atherosclerosis. Trends Cardiovasc Med 2007, 17:118-123.

62. Vasina E, Heemskerk JW, Weber C, Koenen RR: Platelets and platelet-derived microparticles in vascular inflammatory disease. Inflamm Allergy Drug Targets 2010, 9:346-354.

63. Yaguchi A, Lobo FL, Vincent JL, Pradier O: Platelet function in sepsis. J Thromb Haemost 2004, 2:2096-2102.

64. Vincent JL, Yagushi A, Pradier O: Platelet function in sepsis. Crit Care Med 2002, 30(5 Suppl):S313-317

65. Akca S, Haji-Michael P, de Mendonca A, Suter P, Levi M, Vincent JL: Time course of platelet counts in critically ill patients. Crit Care Med 2002 30:753-756.

66. Mavrommatis AC, Theodoridis T, Orfanidou A, Roussos C, ChristopoulouKokkinou V, Zakynthinos S: Coagulation system and platelets are fully activated in uncomplicated sepsis. Crit Care Med 2000, 28:451-457.

67. Antczak AJ, Vieth JA, Singh N, Worth RG: Internalization of IgG-coated targets results in activation and secretion of soluble CD40 ligand and RANTES by human platelets. Clin Vaccine Immunol 2011, 18:210-216.

68. Jenne CN, Wong CH, Petri B, Kubes P: The use of spinning-disk confocal microscopy for the intravital analysis of platelet dynamics in response to systemic and local inflammation. PLoS One 2011, 6:e25109.

69. Gawaz M, Dickfeld T, Bogner C, Fateh-Moghadam S, Neumann FJ: Platelet function in septic multiple organ dysfunction syndrome. Intensive Care Med 1997, 23:379-385.

70. Secor D, Li F, Ellis CG, Sharpe MD, Gross PL, Wilson JX, Tyml K: Impaired microvascular perfusion in sepsis requires activated coagulation and P-selectin-mediated platelet adhesion in capillaries. Intensive Care Med 2010, 36:1928-1934.

71. DeJoy SQ, Jeyaseelan R Sr, Torley LW, Pickett WC, Wissner A, Wick MM, Oronsky AL, Kerwar SS: Effect of CL 184,005, a platelet-activating factor antagonist in a murine model of Staphylococcus aureus-induced grampositive sepsis. J Infect Dis 1994, 169:150-156.

72. Suputtamongkol Y, Intaranongpai S, Smith MD, Angus B, Chaowagul W, Permpikul C, Simpson JA, Leelarasamee A, Curtis L, White NJ: A double-blind placebo-controlled study of an infusion of lexipafant (Platelet-activating factor receptor antagonist) in patients with severe sepsis. Antimicrob Agents Chemother 2000, 44:693-696.

73. Levi M, Schouten $M$, van der Poll T: Sepsis, coagulation, and antithrombin: old lessons and new insights. Semin Thromb Hemost 2008, 34:742-746.

74. Cavaillon JM, Adib-Conquy M, Fitting C, Adrie C, Payen D: Cytokine cascade in sepsis. Scand J Infect Dis 2003, 35:535-544.

75. Panes O, Matus V, Saez CG, Quiroga T, Pereira J, Mezzano D: Human platelets synthesize and express functional tissue factor. Blood 2007, 109:5242-5250

76. Muller I, Klocke A, Alex M, Kotzsch M, Luther T, Morgenstern E, Zieseniss S, Zahler S, Preissner K, Engelmann B: Intravascular tissue factor initiates coagulation via circulating microvesicles and platelets. FASEB J 2003, 17:476-478

77. Osterud B: Tissue factor expression by monocytes: regulation and pathophysiological roles. Blood Coagul Fibrinolysis 1998, 9 Suppl 1:S9-14.

78. McMaken S, Exline MC, Mehta P, Piper M, Wang Y, Fischer SN, Newland CA, Schrader CA, Balser SR, Sarkar A, Baran CP, Marsh CB, Cook CH, Phillips GS, Ali NA: Thrombospondin-1 contributes to mortality in murine sepsis through effects on innate immunity. PloS One 2011, 6:e19654.

79. Brunetti M, Martelli N, Manarini S, Mascetra N, Musiani P, Cerletti C, Aiello FB, Evangelista V: Polymorphonuclear leukocyte apoptosis is inhibited by platelet-released mediators, role of TGFbeta-1. Thromb Haemost 2000, 84:478-483.

doi:10.1186/cc12716

Cite this article as: Garraud O, et al.: Bench-to-bedside review: Platelets and active immune functions - new clues for immunopathology? Critical Care $2013,17: 236$ 
B cells:

- Plasma Cells:

Endothelial Cells:

- Activation

- Inflammation

- Angiogenesis

- Memory B cells:

inody secretion

Memory response

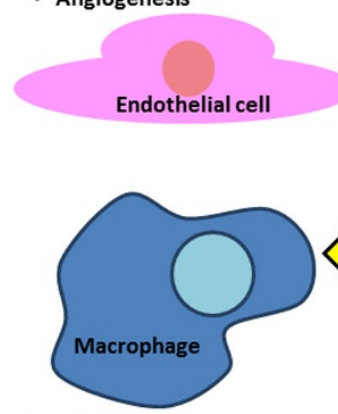

Activated macrophages:

- T cells activation

- Antimicrobial functions

\section{Figure 1}

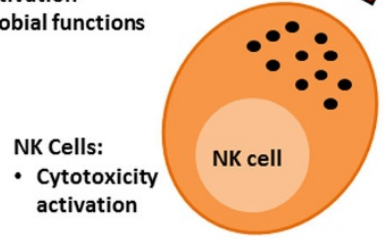

Neutrophils:

- Anti-bacterial proteins

- Increased adhesion
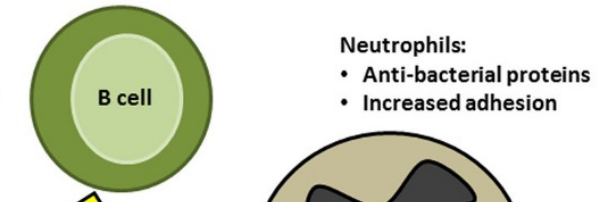

T cells:

- Th1: Inflammatory response

- Th2: Humoral response

- Treg: T-cell regulation and suppression
Mature DC:

- Antigen presentation

- Immune activation CD40 to CD40 Ligand CD40 Ligand to CD40 